\title{
Kirjastotiede ja sivistysteoria
}

Väitöskirjassaan Kirjojen lukeminen ja yleiset kirjastot (1983) Pertti Vakkari tutkii kirjojen lainausta yleisissä kirjastoissa. Hän selvittää myös, mitä muita kanavia (kirjakaupat, kioskit, tuttavat) lukijat käyttävät hankkiessaan kirjoja (jättäen kuitenkin huomiotta muut kirjastot). Pyrkimyksenä on mm. vastata klassiseen kysymykseen "miksi koko aikuisväestö ei lainaa tai muuten käytä kirjastoa.'”

Vakkarin tutkimuksen tehtävänä on tuottaa entistä tarkempaa ja sovellutuskelpoisempaa tietoa yleisöstä kirjastosuunnittelun tarpeisiin. Tehtävänä on varsinkin pohtia, miten kirjasto voisi saada uusia lainaajia.

Vakkarin väitöskirjan heikkous on siinä, että hän ei perusteellisesti pohdi kirjaston tehtävää, ja varsinkin siinä, että hän ei ota kirjaston tehtävään mitään kantaa. Jos näet tarkoituksena on tuottaa kirjastosuunnittelua palvelevaa tietoa, täytyy ottaa kanta kirjaston tehtävään; eihän muuten voi tietää, minkälainen tieto palvelee kirjastosuunnittelua. Tutkimuksesta voi tulla nollatutkimusta.

Vakkari jakaa yleisön kirjaston käytön kannalta kolmeen ryhmään: 1) lainaajat; 2) kirjastoa muuten kuin lainaamalla käyttävät; 3) kirjastoa käyttämättömät.

Viimeksi mainitussa ryhmässä on sellaisia, jotka lukevat kirjoja ja jotka eivät lue. Kirjoja lukemattomia Vakkari ei varsinaisesti tutki.

Vakkari saa mm. tulokseksi, että runsaasti lainaavat ovat korkealla koulutustasolla ja että kirjastoa käyttämättömiin kuuluu kioskikirjallisuutta lukevia, jotka ostavat kirjansa kioskeista.

Vakkari pitää yleisön tutkimista näin ryhmitettynä hyvin tärkeänä, koska vertailemalla ryhmien välisiä eroja löydetään seikkoja, jotka edistävät tai ehkäisevät kirjaston käyttöä kirjojen hankintaan (s. 67). Ts. saadaan tietoja, joita voidaan käyttää hyväksi, kun kakkos- ja kolmosryhmään kuuluvat koetetaan saada siirtymään ykkösryhmään eli tehdä ei-lainaajista lainaajia.

Vakkari pohtii myös kysymystä, miten kirjasto voisi saada sellaiset ihmiset lukemaan kirjoja, jotka eivät niitä lue.
Tällainen tutkimus saattaa käydä epämielekkääksi ellei kirjaston tehtävät olekaan sellaiset kuin Vakkari olettaa. Mielestäni kirjaston tehtävänä ei ole saada ei-lainaajat lainaajiksi ja ei-lukijat lukijoiksi.

\section{Kirjaston tehtävä}

Kun kirjastotieteellä on sellaisia empiirisiä tutkimustehtäviä, joita ei voi mielekkäästi suorittaa ottamatta huomioon kirjaston tehtävää, miten kysymys kirjaston tehtävästä on ratkaistava?

Kirjastotieteilijä voi lähteä niistä kirjaston tehtävistä, jotka ovat positiivisesti olemassa. Kirjastolle on asetettu tehtäviä esim. kirjastoasetuksessa sekä kouluhallituksen ja kuntien kirjastolautakuntien päätöksissä. Näiden virallisesti määrättyjen tehtävien lisäksi kirjastolle suositellaan tehtäviä esim. julkisessa keskustelussa.

Jos kirjastotiede lähtee näin asetetuista kirjaston tehtävistä, siitä tulee positivistinen tiede. Se ei ota kantaa arvoihin, joista loppujen lopuksi on aina kysymys kirjaston tehtävää asetettaessa. Tässä merkityksessä positivistinen kirjastotiede on epäkriittistä.

Lähtemällä kirjastolle asetetuista tehtävistä kirjastotiede ei pääse pitkällekään. Virallisesti määrätyt tehtävät ovat liian ylimalkaisia. Julkisessa keskustelussa ehdotetut tehtävät ovat keskenään ristiriidassa.

Toinen tie on se, että kirjastotieteilijä pohtii kriittisesti kirjastolle asetettuja tehtäviä ja ottaa niihin omakohtaisesti kannan. Tällöin hän nojaa toisaalta esim. lukemistutkimuksen paljastamiin tosiasioihin, toisaalta praktiseen filosofiaan (kulttuurifilosifiaan, arvofilosofiaan, etiikkaan). Kirjastotiede ei ole tällöin kauttaaltaan 'tieteellistä"' sanan positiivisessa merkityksessä, vaan se on osittain myös filosofista.

Tarkkaan katsoen Vakkari ei ehkä ota mitään kantaa kirjaston tehtävään. Hänen asenteensa on hypoteettinen: jos kirjaston tehtävänä on se ja se, tämän tehtävän suorittamiseksi kirjastotieteen pitää hankkia sellaisia ja sellaisia tietoja. 
Tällöin kirjastotiede joutuisi rannattomien tutkimustehtävien eteen. Mielestäni kirjaston tehtävänä ei voi olla kaikkien kirjaston käyttäjien saaminen lainaajiksi. Kun käyn Lohjan kirjastossa lukemassa aikakauslehtiä ja ulkomaisia tietosanakirjoja, miksi kirjastovirkailijan pitäisi yrittää saada minut lainaamaan esim. Mehiläishoidon oppaan tai Saarikosken runokokoelman?

Vakkarin mukaan eräs mahdollinen kirjaston tehtävä on saada kirjoja lukevat lainaamaan tarvitsemansa kirjat kirjastosta. Tähän ryhmään kuuluu esim. sellaisia, jotka ostavat kirjoja itselleen. Ostaminen saattaa johtua siitä, että heidän haluamiaan kirjoja ei ole kirjastossa. Saadakseen nämä henkilöt lainaajiksi, kirjaston täytyy tietyllä tavalla täydentää varastoaan.

Mielestäni kirjaston tehtävänä ei ole muuttaa kirjojen ostajat kirjojen lainaajiksi. Jos kirjasto tässä tehtävässä täydellisesti onnistuisi, seurauksena olisi kirjakauppojen ja pian myös kotikirjastojen häviäminen. Tällöin kirjastosta tulisi ainoa kirjallisuuden hankintakanava. Kun kirjastot ovat poliitikkojen hallinnassa he kontrolloisivat täydellisesti, mitä kirjoja kansalaiset saavat luettavikseen.

Vakkari ei ota lainkaan pohdittavakseen, mitä yhteiskunnallisia seurauksia on siitä, miten kirjaston tehtävä asetetaan. Positivistinen kirjastotiede ei tietenkään voi ottaa kantaa esim. siihen, onko hyvä vai paha, että kirjasto on ainoa kirjanhankintakanava, mutta se voi kuitenkin analysoida, minkälaisia seurauksia tästä on. Tällöinkin kirjastotiede suorittaisi osittain kriittistä tehtävää.

Vakkari ei kerro, miksi hän ottaa tutkimuksensa lähtökohdaksi sellaisen otaksuman, että kirjaston tehtävänä on saada kaikki (tai mahdollisimman monet) lukemaan ja lainaamaan kirjoja. Ainakaan Suomessa kirjastolle ei ole asetettu koskaan tällaista tehtävää virallisesti tai edes puolivirallisesti. Tehtävä onkin niin mieletön, että Vakkarikin suhtautuu siihen parissa paikassa hieman kriittisesti.

Hän näet viittaa siihen, että praktisen lukemisen (lukeminen käytännössä tarvittavan tiedon saamiseksi) voi korvata jokin muu tietolähde, jollaisia jo kirjastoissakin on tarjolla. Periaatteessa kuitenkin jokainen kirjallisuuden laji on jossakin määrin korvattavissa. Esim. romaaneista on tehty dramatisointeja teatteria ja elokuvaa varten. Lausuntatilaisuuksissa ja konserteissa voi jossakin määrin tutustua runouteen. Toiseksi Vakkari huomauttaa, että kirjoista kiinnostumattomat saattavat harrastaa "muita, kenties yhtä arvokkaita asioita."
Kirjojen lukeminen, ei edes lukeminen ole ainoa autuaaksi tekevä asia. Suomalaisessa yhteiskunnassa on monenlaisia muita mahdollisuuksia hankkia itselleen tietoa ja sivistystä: radio, televisio, videot, kasetit, teatteri, esitelmä- ja keskustelutilaisuudet sekä aikuiskasvatuksen laaja verkosto.

Suomessa kirjaston tehtävää on traditionaalisesti tarkasteltu lähtemällä siitä, että kirjasto on eräs instituutio sivistyslaitosten kokonaisuudessa. Tämä todetaan myös kirjastoasetuksessa, jonka mukaan "yleisten kirjastojen tarkoituksena on kirjastolaitokselle ominaisin toimintamuodoin tyydyttää yleistä sivistystarvetta ja lukuharrastusta."

Jos kirjastotiede tahtoo lähteä tästä, sen on omaksuttava jokin jo olemassaoleva sivistysteoria tai luotava uusi.

Sivistysteoria on filosofinen asia.

Toiseksi kirjastotieteen täytyy luoda kuva siitä, minkälainen yleinen sivistystarve yhteiskunnassa on. Eräs sivistystarve on lukemisen tarve.

Sivistystarpeen tutkiminen on luonteeltaan empiiristä.

Kolmanneksi kirjastotieteen tehtävänä on selvittää, miten sivistystarvetta voidaan tyydyttää kirjastolaitokselle ominaisin toimintamuodoin.

\section{Sivistysteoria}

Kieleemme muodostettiin 1800-luvun alussa sana sivistys, kun tahdottiin omaksua saksalaisen uushumanismin sivistysteoria (Theorie der Bildung). Viime aikoina käyty keskustelu aikuiskasvatuksen, erityisesti vapaan sivistystyön ihmis- ja sivistyskäsityksestä on osoittanut, että traditionaalisesta sivistysteoriasta tahdotaan edelleenkin pitää kiinni erittäin yksimielisesti.

Mielestäni myös kirjaston tehtävä on nähtävä tämän sivistysteorian pohjalta.

Traditionaalisen sivistysteorian mukaan sivistys on yksilöllistä. Jokaisella ihmisellä on omat sivistystarpeensa ja -harrastuksensa. Tämä ei sulje pois sitä, että erilaisilla sosiaalisilla ja maantieteellisillä ryhmillä on yhteisiä tarpeita ja harrastuksia. Niinpä voidaan puhua esim. työväen ja maaseudun sivistyksestä. Jollakin pitäjällä, jopa kylälläkin voi olla sille ominaista sivistyselämää.

On siis luonnollista, että joku harrastaa erikoisesti esim. teatteria, joku kirjallisuutta. Nämä harrastukset eivät välttämättä sulje pois toisiaan. Päinvastoin teatterista kiinnostunut voi tuntea tarvetta syventyä teatteritaiteeseen myös kirjallisuuden avulla ja Aleksis Kiven lu- 
kija saattaa haluta nähdä Seitsemän veljestä myös näyttämöllä.

Kirjaston ei sovi pyrkiä saamaan kaikki ihmiset asiakkaikseen voimavarojaan tuhlaten, ei myöskään teatterin, musiikkielämän, taidenäyttelyiden jne. Ei ihminen pysty kaikkea kunnolla harrastamaan. Tuloksena olisi vain puolisivistys (Halbbildung). Sivistysharrastusten kasaantuminen on mahdollista vain tiettyyn rajaan asti. Rajan asettaa aikapula.

Vakkari osoittaa, että tottumus käyttää kirjastoa voidaan juurruttaa jo nuorena. Se on mielestäni hyvä tottumus. Mutta hyvä on myös kasvattaa ihmiset pienestä pitäen hankkimaan itselleen kunnollinen kotikirjasto.

\section{Tasa-arvoisuus}

Tasa-arvoisuuden nimissä on vaadittu, että kaikki väestöryhmät pitäisi saada käyttämään kirjastoa hyväkseen (yhtä paljon). Nythän kaikki eivät käy kirjastossa ollenkaan. Vähän lukevat ja heikoimmin koulutetut käyvät kirjastossa vain harvoin.

Yhtenä keinona kirjastonkäytön tasa-arvostamiseksi on esitetty, että kirjastoihin hankittaisiin viihdekirjallisuutta (esim. teoksessa Lainakirja, 1973, s. 157). Myös Vakkari katsoo tarpeelliseksi pohtia, miten kirjasto voisi tasaarvoistamistehtävänsä suorittaa. Hän päätyy mm. sellaiseen tulokseen, että kirjaston on kutakuinkin mahdotonta saada sellaiset ihmiset lukemaan, joita kirjat eivät laisinkaan kiinnosta.

Vakkari ei kysy, pitääkö kirjastolle asettaa tasa-arvoistamistehtävä.

Puhuttaessa tasa-arvoisuudesta kirjaston yhteydessä sillä tarkoitetaan egalitaristista tasa-arvoisuutta eli samanlaisuutta. Tasa-arvo toteutuisi esim. silloin, kun kaikki lainaavat kirjastosta yhtä monta teosta niiden laadusta riippumatta.

Pidän pyrkimystä tällaiseen numeeriseen tasa-arvoon mielettömänä.
Viittasin edellä siihen, että sivistyksen ei tarvitse eikä se voikaan olla jokaisen yksilön ja ryhmän kohdalla samanlaista. Mainitsin myös, että samantapainen sivistys voidaan hankkia sangen erilaisin keinoin. Kirjojen lukeminen ei ole mikään absoluuttinen sivistyksen mitta.

Humanistinen sivistysteoria ei voi olla tekemättä eroa hyvän ja huonon kirjallisuuden välillä. Kirjoituksessani Arvonihilistinen kirjasto olen osoittanut, minkälaisiin vaikeuksiin jouduttaisiin, jos kirjavalinnassa arvonäkökohdat syrjäytettäisiin.

Kirjaston ei sovi haalia lainaajia esim. siten, että kirjastoon hankittaisiin viihde- eli ajanvietekirjallisuutta. Kun Aikuiskoulutuskomitea väittää mietinnössään (s. 200), että kirjastoasetuksessa mainittu lukuharrastuksen tyydyttäminen antaa luvan viihdekirjallisuuden hankintaan, en usko tätä ilman todisteita. Mielestäni kirjastoon pitää hankkia vain hyvää kirjallisuutta, mutta pieni osa viihdekirjallisuudesta on hyvää kirjallisuutta.

Kaikki harrastukset eivät ole hyviä, eivät lukuharrastuksetkaan. Kuten kansalaisopiston ei sovi tyydyttää kaikkia harrastuksia, kirjastonkaan ei pidä tyydyttää kaikenlaisia lukuharrastuksia.

Kirjasto ei ole mitään luokkaa, esim. lukeneistoa varten. Se on tasavertaisesti avoin kaikille. Mutta kirjastolla on jotakin tarjottavana vain niille, jotka tahtovat tyydyttää sivistystarpeitaan ennen kaikkea kirjallisuuden avulla.

\section{Lähteet}

Harva, U.: Arvonihilistinen kirjasto. Kirjastolehti $21 / 1965$

Nuotio, S. Perälä, K. Putkonen, A. Gronow, P.: Lainakirja. Helsinki: Tammi. 1973.

Vakkari, P.: Kirjojen lukeminen ja yleiset kirjastot. Kirjastopalvelu Oy. 1983. 